anthropology \& materialism

\section{Anthropology \& Materialism}

A Journal of Social Research

$3 \mid 2016$

Utopia: The Elsewhere and The Otherwise

\title{
Residuos matéricos
}

Larraquy, Roque (2014). Informe sobre ectoplasma animal. Ilustraciones de Diego Ontivero. Buenos Aires: Eterna cadencia ( 82 pp.)

\section{Elsa R. Brondo}

\section{Q OpenEdition}

1 Journals

\section{Edición electrónica}

URL: http://journals.openedition.org/am/602

DOI: $10.4000 / a m .602$

ISSN: 2364-0480

\section{Editor.}

CETCOPRA, CRASSH - Center for Research in the Arts Social Sciences and Humanities, Fakultät Gestaltung - Universität der Künste Berlin

\section{Referencia electrónica}

Elsa R. Brondo, « Residuos matéricos », Anthropology \& Materialism [En línea], 3 | 2016, Publicado el 25 noviembre 2016, consultado el 21 abril 2019. URL : http://journals.openedition.org/am/602 ; DOI : $10.4000 / a m .602$

Este documento fue generado automáticamente el 21 abril 2019.

Tous droits réservés 


\section{Residuos matéricos}

Larraquy, Roque (2014). Informe sobre ectoplasma animal. Ilustraciones de Diego Ontivero. Buenos Aires: Eterna cadencia (82 pp.)

\section{Elsa R. Brondo}

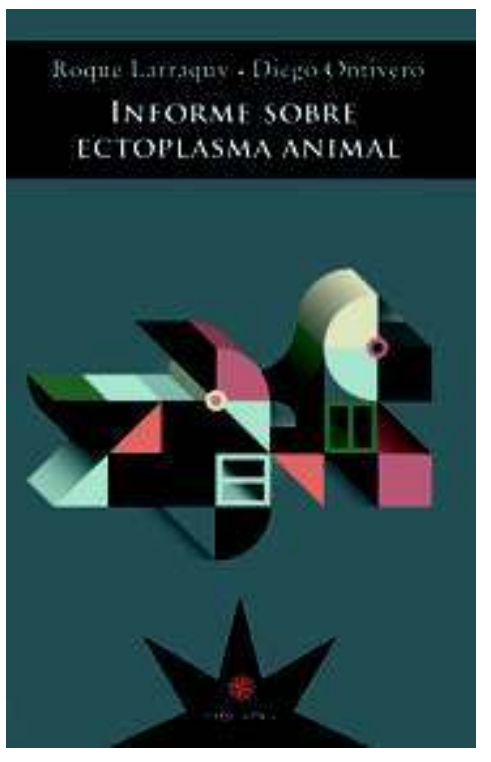

1 Informe sobre ectoplasma animal de Roque Larraquy es una novela corta y fragmentaria que sostiene su unidad en un tono cientificista y en las geométricas ilustraciones de Diego Ontivero, imágenes que dialogan con las manifestaciones etéricas de animales muertos. El título mismo prefigura la naturaleza de la narración, sobre todo el término ectoplasma. La palabra se la debemos al premio nobel francés Charles Richet, quien en 1894 definió el ectoplasma como la "emanación material de un médium, con la que se dice que se forman apariencias de fragmentos orgánicos, seres vivos o cosas" (Diccionario de RAE). ${ }^{1}$ La novela de Larraquy, sin embargo, convierte el ectoplasma en un registro fotográfico de la manifestación de un espectro animal. La cámara se convierte en el médium, a través del cual el mundo concreto establece contacto con las huellas del más allá.

2 Las crónicas y capítulos que forman parte de Informe sobre ectoplasma animal están fechados de 1911 a 1957, pero aglutinados, en desorden cronológico, en cuatro apartados. 
Se comienza por los años más recientes de la historia, que va de 1940 a 1957, con relatos que consignan el trabajo de la ectografía. "Federico. Buenos Aires, 1949", texto que abre el volumen, describe una presencia invisible que impide a una familia el paso a su casa; Julio Heiss - un ectografista- descubre, a partir de una serie de fotografías espectrales, la presencia de Federico, el perro de la familia muerto en el umbral de la casa en 1948. Páginas más tarde, en el tercer apartado, se nos revela el origen de esta práctica forense: Severo Solpe es el artífice de la técnica de fotografía ectoplásmica o ectografía animal. A partir de un engaño fotográfico en donde aparecen animales fantasmales, "a pedido de un Senador de la Nación que quiere impresionar a unas señoritas" (45), en 1911 Solpe da accidentalmente con la imagen real de la presencia etérica de un pato muerto.

Imaginemos, entonces, la manifestación luminosa de la muerte: "la inscripción en éter de un animal muerto como espectro mensurable por su claridad en watts, resulta de los hábitos que el animal supo reiterar en vida y del sufrimiento físico intenso" (51; el subrayado es mío). Las inscripciones eléctricas de los animales tienen relación directa con su muerte violenta y aparecen en el lugar en que estrambóticos sucesos la han producido. Los animales perecen a manos de la omisión, el descuido o la crueldad humana. Esta relación es fundamental, porque la "fotografía ectoplásmica" únicamente registra la reminiscencia de animales "que históricamente vio con vida" (39) una persona. Incluso las presencias, antes de ser registradas, son percibidas y en ocasiones producen efectos físicos desagradables en la gente.

4 Severo Solpe es el eje de Informe sobre ectoplasma animal, no sólo por ser el pionero y descubridor de la técnica, sino porque convierte su práctica en institución al fundar la Sociedad Ectográfica Argentina. Establecida en un edificio de Buenos Aires, la sociedad opera como un laboratorio experimental, en donde los animales son sometidos a toda clase de torturas. En septiembre de 1930, Solpe establece un intercambio epistolar con un político para obtener vigilancia nocturna y apoyo económico. En esas cartas relata lo imprescindible para describir la naturaleza "científica" del maltrato y asesinato de animales en aras de su investigación; también minucias personales y eventos parapsicológicos que se verifican en el edificio, pero sobre todo, coquetea con los usos de la ectografía y las manifestaciones etéricas "como posible herramienta ofensiva para regulación y control de asuntos nacionales" (79; el subrayado es mío). En el libro se omiten las referencias históricas, aun cuando el apartado nodal del Informe esté ubicado en la primera quincena del mes de septiembre de 1930 . Se elude, también, la mención al día del primer golpe de Estado en la Argentina. El 6 de septiembre el presidente Hipólito Irigoyen, electo democráticamente, es depuesto por el general José Félix Uriburu, quien formaría un gobierno de facto de 1930 a1932. Tanto Uriburu como su sucesor, elegido en las urnas, el general Agustín P. Justo (1932-1938) instauraron la censura, represión y tortura como prácticas de control social.

5 En las crónicas que componen su Informe sobre ectoplasma animal, Roque Larraquy logra crear el tono positivista de la ciencia en la primera mitad del siglo xx y la austeridad de un lenguaje que remeda el estilo de los expedientes legales y científicos de la época. Con todo ello aparece una Argentina instalada en una "modernidad" asediada por los espíritus y la técnica, en donde la fotografía cobra el papel de mediador en una sociedad secularizada, a la vez que creyente de fenómenos paranormales. Larraquy abreva del vínculo que estableció el espiritismo decimonónico con las falsas pruebas fotográficas, que a principios del siglo xx proliferaron en Occidente, pero esta vez la ficción le otorga veracidad a los registros. 
6 En la lógica de la novela de Larraquy, el fenómeno del ectoplasma es una construcción forense que introduce a los animales como sujetos de la violencia humana y también como una serie de metáforas de la sobrevivencia del dolor como huella. La memoria social se manifiesta en los márgenes, desde la animalidad, y el sufrimiento se desplaza hacia la aparente inocencia de una Sociedad privada, que lleva a cabo un trabajo de investigación con animales. El poder político es el punto en el que la tortura y su rastro pueden alcanzar a los seres humanos, porque una vez registrado el ectoplasma, la presencia incómoda del sujeto y su dolor se localizan y controlan. Las manifestaciones de los residuos matéricos (espectros o espíritus) son registrados por la cámara y también engullidos por este registro, de manera que la técnica produce una inscripción $\mathrm{y}$, al mismo tiempo, su confinamiento en un archivo. ¿Borrar a sus fantasmas no sería la ilusión de todo régimen represivo?

7 La originalidad de Larraquy radica en transitar tangencialmente por el tema de la violencia social y eludir los lugares visitados por otras narraciones que suelen explorar la historia reciente de las dictaduras, a partir del golpe de Estado de 1976 en la Argentina. En su brevedad, el Informe sobre ectoplasma animal es un artefacto inquietante, que dibuja las elusivas huellas del sufrimiento en nuestro continente.

\section{NOTAS}

1. A principios del siglo $\mathrm{xx}$, lo pseudocientífico y los fenómenos parapsicológicos convivían con la ciencia y los avances tecnológicos. La fotografía y la credibilidad que producía, de hecho, permitieron a muchos charlatanes hacer montajes en los que se podía ver a una mujer en trance, arrojando fantasmas por su boca. Libros y artículos, como el célebre Spiritism and Common Sense de Heredia de 1922, demostraron los trucos evidentes de las emanaciones de ectoplasmas que salían de los médiums en trance, pero eso no evitó la fascinación y los crédulos seguidores, entre los que se contaba a Sir Arthur Conan Doyle.

\section{AUTOR}

\section{ELSA R. BRONDO}

Profesora de Teoría Literaria, Facultad de Filosofía y Letras de la Universidad Nacional Autónoma de México (UNAM) 